Review article

\title{
The presence of respiratory disorders in individuals with low back pain: A systematic review
}

\author{
Nele Beeckmans a, b, c, 1 , Astrid Vermeersch ${ }^{\text {a, b, }}{ }^{\text {, }}$, Roeland Lysens ${ }^{\text {a }}$, Peter Van Wambeke ${ }^{\text {a }}$, \\ Nina Goossens ${ }^{\mathrm{d}}$, Tinne Thys ${ }^{\mathrm{a}}$, Simon Brumagne ${ }^{\mathrm{a}, \mathrm{d}}$, Lotte Janssens ${ }^{\mathrm{d}, \mathrm{e}, *}$ \\ ${ }^{a}$ University Hospitals Leuven, Department of Physical Medicine and Rehabilitation, Herestraat 49, 3000 Leuven, Belgium \\ ${ }^{\mathrm{b}} \mathrm{KU}$ Leuven - University of Leuven, Faculty of Medicine, Herestraat 49, 3000 Leuven, Belgium \\ ${ }^{c}$ University Hospitals Saint-Luc, Department of Physical Medicine and Rehabilitation, Hippokrateslaan 10, 1200 Sint-Lambrecht-Woluwe, Belgium \\ ${ }^{\mathrm{d}}$ KU Leuven - University of Leuven, Department of Rehabilitation Sciences, Tervuursevest 101 Box 1501, 3001 Leuven, Belgium \\ ${ }^{\mathrm{e}}$ Hasselt University, Biomedical Research Institute, Agoralaan A, 3590 Diepenbeek, Belgium
}

\section{A R T I C L E I N F O}

\section{Article history:}

Received 4 April 2016

Received in revised form

14 July 2016

Accepted 16 July 2016

\section{Keywords:}

Back pain

Comorbidities

Smoking

Asthma

Respiratory disorder

\begin{abstract}
A B S T R A C T
Background: Inspiratory muscles, such as the diaphragm, play a key role in both respiration and spinal control. Therefore, diaphragm dysfunctions are often related to low back pain (LBP). However, few is known on the association between the presence of LBP and the presence of respiratory disorders (RD). Objectives: To perform a systematic review on the relation between RD and LBP.

Study design: Systematic review.

Methods: Two reviewers searched on PubMed/MEDLINE for studies concerning LBP and RD, from 1950 up to January 2016. The search string consisted of the following key words: low back pain, dyspnea, respiratory problems, lung diseases, comorbidity, pulmonary disease, chronic obstructive, smoking, asthma, allergy, sinusitis, respiratory tract infection and hyperventilation. The aim was to evaluate a potential correlation, co-occurrence or causality between RD and LBP.

Results: A total of 16 articles were included. A significant correlation between the presence of LBP and the presence of RD such as dyspnea, asthma, different forms of allergy, and respiratory infections was found. No correlation was found between Chronic Obstructive Pulmonary Disease (COPD) and LBP, and no articles were found on the correlation between hyperventilation and LBP.

Conclusions: This is the first study providing an overview of the literature on the relation between LBP and RD. Immunological, biomechanical, psychosocial and socio-economic factors might explain this correlation. Smoking is likely to contribute. Future studies must reveal the causative relationship. Level of evidence: Therapy, level $2 \mathrm{a}$.
\end{abstract}

(c) 2016 Elsevier Ltd. All rights reserved.

\section{Introduction}

Low back pain (LBP) is worldwide one of the most important medical conditions in terms of reduced quality of life, disability and socio-economic costs. LBP has a life-time prevalence of $84 \%$. About $10 \%$ of all patients with an acute episode of LBP develop chronic LBP

\footnotetext{
* Corresponding author. KU Leuven - University of Leuven, Department of Rehabilitation Sciences, Tervuursevest 101 Box 1501, 3001 Leuven, Belgium.

E-mail addresses: Nele_Beeckmans@hotmail.com (N. Beeckmans), Astrid. Vermeersch@gmail.com (A. Vermeersch), Roeland.Lysens@uzleuven.be (R. Lysens), Peter.VanWambeke@uzleuven.be (P. Van Wambeke), Nina.Goossens@ kuleuven.be (N. Goossens), Tinne.Thys@uzleuven.be (T. Thys), Simon.Brumagne@ kuleuven.be (S. Brumagne), Lotte.Janssens@kuleuven.be (L. Janssens).

${ }^{1}$ Joint first authors.
}

(i.e. lasting longer than 3 months). LBP affects men and women equally. The prevalence peaks between 35 and 55 years old and has a complex etiopathogenesis with multiple intrinsic and extrinsic risk factors (Balagué et al., 2012).

Decreased postural control appears to be associated with the presence of LBP (Ruhe et al., 2011). Although the causal link is not fully clear yet, it is known that dominant use of ankle proprioception during postural control relates to the development and recurrence of LBP (Claeys et al., 2015). The inspiratory muscles (IM), and specifically the diaphragm, have a key role in controlling the spine, which is crucial during postural control (Hodges and Gandevia, 2000). However, during loading of the IM, the use of back proprioceptive signals, necessary for balance control, is reduced in individuals with LBP (Janssens et al., 2010) and in 
patients with Chronic Obstructive Pulmonary Disease (COPD) (Janssens et al., 2013b). Furthermore, individuals with LBP showed greater susceptibility to diaphragm fatigue compared to healthy controls (Janssens et al., 2013a). Recently, this research group found that targeted training of the IM in individuals with LBP improved postural control and significantly lowered the severity of LBP (Janssens et al., 2015).

Respiratory muscle weakness and diaphragm fatigue are also found in some patients with COPD during high-intensity exercise (Decramer et al., 1980; Polkey et al., 1996; Bachasson et al., 2013). Patients with more hyperinflation during exercise showed greater diaphragm fatigue. The latter can be explained by diaphragm flattening and thus an impaired pressure-generating capacity, resulting in a limited contribution of the diaphragm to IM work (McKenzie et al., 2009). Likewise, exacerbations of asthma, airway closure and expiratory airflow limitation can result in hyperinflation. This in turn, compromises the stabilizing function of the diaphragm (Hill, 1991).

Important questions that arise are whether and, if so, to what extent, patients with LBP are susceptible to having a respiratory disorder (RD) and vice versa. To the best of our knowledge, this is the first systematic review providing an overview of the literature on the relation between the presence of RD and the presence of LBP. If there is indeed a correlation, further research must reveal if IM training can be a valuable tool in the rehabilitation of specific subpopulations of individuals with LBP.

\section{Material and methods}

\subsection{Literature search strategy}

A computerized search in the PubMed/MEDLINE database was conducted independently by two reviewers (A.V. and N.B.) from 1950 up to January 2016. The search string consisted of combinations of the following key words and Medical Subject Headings (MeSH): low back pain [Mesh], dyspnea [Mesh], respiratory problems, lung diseases [Mesh], comorbidity [Mesh], pulmonary disease, chronic obstructive [Mesh], smoking [Mesh], asthma [Mesh], allergy, sinusitis [Mesh], respiratory tract infection [Mesh] and hyperventilation [Mesh]. After the computerized search, reference lists of all selected articles were manually checked for additional relevant articles. After de-duplication, the two reviewers independently screened each article to select the potentially relevant studies from titles, abstracts, and keywords. If any of the inclusion criteria were not met, the article was excluded from further consideration. Remaining articles were then screened based on full-text.

\subsection{Eligibility criteria for considering studies for this review}

Eligibility assessment of the obtained articles was performed independently by the two reviewers (A.V. and N.B) by screening the articles based on predefined in- and exclusion criteria.

\subsubsection{Eligibility criteria for types of study}

The following criteria were used to exclude articles from further consideration: published prior to 1950 , not written in Dutch or English, did not include human data, contained no original data, abstract or conference proceeding, no full text available, or article not meeting the topic.

\subsubsection{Eligibility criteria for types of participants}

Study participants had to be female and male adults of at least 18 years old, who reported or had been diagnosed with any type of LBP and any type of RD.

\subsubsection{Eligibility criteria for outcomes}

To be included, articles had to investigate a relation, cooccurrence or causality between LBP and RD.

\subsection{Risk of bias in included studies}

Risk of bias of all included studies was assessed independently by two reviewers (A.V. and N.B.) by using the STrengthening the Reporting of OBservational studies in Epidemiology (STROBE) statement for cohort case-control and cross-sectional studies (von Elm et al., 2008). We used the principles from the Grading of Recommendations Assessment, Development, and Evaluation (GRADE) working group to summarize the body of evidence overall. It was judged that the data were not suitable for statistical pooling due to the heterogeneity of the study designs. Therefore, the results were summarized qualitatively. Disagreements were resolved through consensus with other authors.

\subsection{Data collection and analysis}

After the initial assessment for eligibility, the two reviewers independently extracted the following data from the included studies: study design, sample size, sex, age, type of LBP, type of RD, and main study result.

\section{Results}

A flowchart of the literature search is shown in Fig. 1. A total of 16 articles were included. The results of the quality assessment of each study are shown in Table 1 . Study results are presented in Table 2. One article described the relation between LBP and dyspnea, six articles investigated the relation of LBP with non-specified

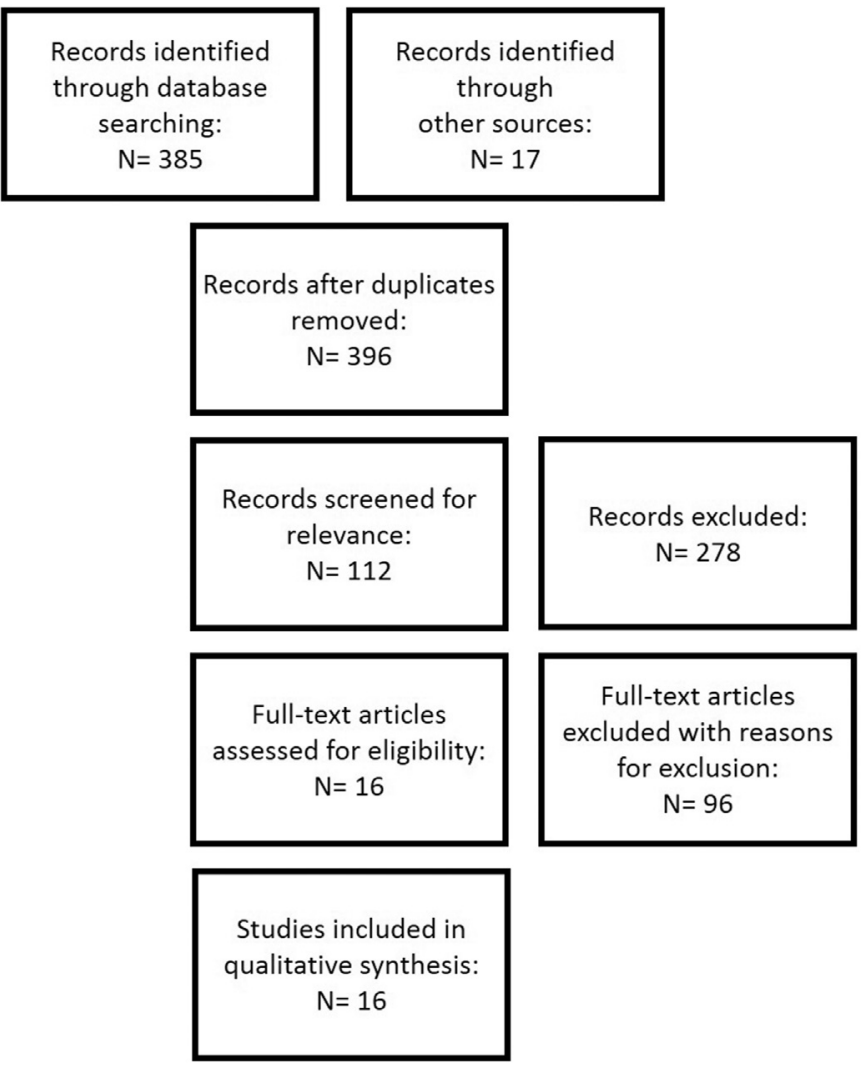

Fig. 1. PRISMA flow chart of study-selection process. 
Table 1

Risk of bias (STROBE) and level of evidence (GRADE) assessment.

\begin{tabular}{|c|c|c|c|c|c|c|c|c|c|c|c|c|c|c|c|c|}
\hline & $\begin{array}{l}\text { Åstrand, } \\
1987\end{array}$ & $\begin{array}{l}\text { Bartholomeeusen } \\
\text { et al., } 2011\end{array}$ & $\begin{array}{l}\text { Clark et al., } \\
2014\end{array}$ & $\begin{array}{l}\text { Heliovaara } \\
\text { et al., } 1991\end{array}$ & $\begin{array}{l}\text { Hestbaek } \\
\text { et al., } 2004\end{array}$ & $\begin{array}{l}\text { Hestbaek } \\
4 \text { et al., } 2006\end{array}$ & $\begin{array}{l}\text { Hurwitz and } \\
\text { Morgenstern, } \\
1999\end{array}$ & $\begin{array}{l}\text { Laban and } \\
\text { Kucway, } \\
2003\end{array}$ & $\begin{array}{l}\text { McIntosh } \\
\text { et al., } 2006\end{array}$ & $\begin{array}{l}\text { Schäfer et al., } \\
2014\end{array}$ & $\begin{array}{l}\text { Schneider } \\
\text { et al., } 2007\end{array}$ & $\begin{array}{l}\text { Synnot and } \\
\text { Williams, } \\
2002\end{array}$ & $\begin{array}{l}\text { Smith et al., } \\
2006\end{array}$ & $\begin{array}{l}\text { Smith et al., } \\
2009\end{array}$ & $\begin{array}{l}\text { Smith et al., } \\
2014\end{array}$ & $\begin{array}{l}\text { Wright et al., } \\
1995\end{array}$ \\
\hline $1 \mathrm{a}$ & + & - & - & - & + & + & + & + & + & - & - & + & + & + & + & - \\
\hline $1 \mathrm{~b}$ & + & + & + & + & + & + & + & + & + & + & + & + & + & + & + & + \\
\hline 2 & + & + & + & + & + & + & + & + & + & + & + & + & + & + & + & + \\
\hline 3 & + & + & + & + & + & + & + & + & + & + & + & + & + & + & + & + \\
\hline 4 & + & - & + & - & - & - & - & + & + & - & - & + & - & - & - & - \\
\hline 5 & + & + & + & + & + & + & + & + & + & + & + & + & + & + & + & + \\
\hline $6 a$ & + & + & + & + & + & + & + & + & + & + & + & + & + & + & + & + \\
\hline $6 \mathrm{~b}$ & $\mathrm{n} / \mathrm{a}$ & + & $\mathrm{n} / \mathrm{a}$ & $\mathrm{n} / \mathrm{a}$ & $\mathrm{n} / \mathrm{a}$ & $\mathrm{n} / \mathrm{a}$ & $\mathrm{n} / \mathrm{a}$ & + & + & $\mathrm{n} / \mathrm{a}$ & $\mathrm{n} / \mathrm{a}$ & $\mathrm{n} / \mathrm{a}$ & $\mathrm{n} / \mathrm{a}$ & + & + & $\mathrm{n} / \mathrm{a}$ \\
\hline 7 & + & + & + & + & - & - & - & - & + & - & + & + & + & - & - & + \\
\hline 8 & + & + & + & + & + & + & + & - & + & + & + & + & + & + & + & + \\
\hline 9 & + & - & + & - & - & + & - & - & - & - & + & - & - & - & - & + \\
\hline 10 & + & + & + & + & + & + & + & + & + & + & + & + & + & + & + & + \\
\hline 11 & + & - & + & + & - & - & - & - & - & - & - & - & - & - & - & + \\
\hline $12 \mathrm{a}$ & + & + & + & + & - & + & + & - & + & + & + & + & + & + & + & + \\
\hline $12 \mathrm{~b}$ & + & + & + & + & + & + & + & - & + & + & + & + & + & + & + & + \\
\hline $12 c$ & + & - & + & - & - & - & - & - & - & - & - & - & + & - & + & - \\
\hline $12 \mathrm{~d}$ & + & - & - & + & - & - & - & $\mathrm{n} / \mathrm{a}$ & + & + & + & + & + & - & + & - \\
\hline $12 \mathrm{e}$ & - & - & - & - & - & - & - & - & - & - & - & - & - & - & - & - \\
\hline $13 a$ & + & + & + & + & + & + & + & + & + & + & + & + & + & + & + & + \\
\hline $13 \mathrm{~b}$ & - & - & + & - & - & - & - & - & - & $\mathrm{n} / \mathrm{a}$ & + & - & + & - & + & - \\
\hline $13 c$ & - & - & - & - & - & - & - & - & - & $\mathrm{n} / \mathrm{a}$ & + & - & - & - & - & - \\
\hline $14 a$ & + & - & + & + & - & - & + & - & + & - & + & - & - & - & - & - \\
\hline $14 \mathrm{~b}$ & + & - & - & - & - & - & - & - & + & - & - & - & + & + & + & - \\
\hline $14 \mathrm{c}$ & $\mathrm{n} / \mathrm{a}$ & + & $\mathrm{n} / \mathrm{a}$ & $\mathrm{n} / \mathrm{a}$ & $\mathrm{n} / \mathrm{a}$ & + & $\mathrm{n} / \mathrm{a}$ & $\mathrm{n} / \mathrm{a}$ & + & $\mathrm{n} / \mathrm{a}$ & $\mathrm{n} / \mathrm{a}$ & $\mathrm{n} / \mathrm{a}$ & $\mathrm{n} / \mathrm{a}$ & + & + & $\mathrm{n} / \mathrm{a}$ \\
\hline 15 & + & + & + & + & + & - & + & + & + & + & + & + & + & - & - & + \\
\hline $16 a$ & + & + & + & + & + & + & + & - & + & + & + & - & + & + & + & + \\
\hline $16 \mathrm{~b}$ & - & - & - & - & - & - & - & + & - & - & - & + & - & - & - & - \\
\hline $16 c$ & $\mathrm{n} / \mathrm{a}$ & $\mathrm{n} / \mathrm{a}$ & $\mathrm{n} / \mathrm{a}$ & $\mathrm{n} / \mathrm{a}$ & $\mathrm{n} / \mathrm{a}$ & $\mathrm{n} / \mathrm{a}$ & na & $\mathrm{n} / \mathrm{a}$ & $\mathrm{n} / \mathrm{a}$ & $\mathrm{n} / \mathrm{a}$ & $\mathrm{n} / \mathrm{a}$ & $\mathrm{n} / \mathrm{a}$ & $\mathrm{n} / \mathrm{a}$ & $\mathrm{n} / \mathrm{a}$ & $\mathrm{n} / \mathrm{a}$ & $\mathrm{n} / \mathrm{a}$ \\
\hline 17 & + & + & + & + & + & + & + & - & + & + & + & + & - & - & - & + \\
\hline 18 & + & + & + & + & + & + & + & + & + & + & + & + & + & + & + & + \\
\hline 19 & + & + & + & + & + & - & + & - & + & + & + & - & + & + & + & + \\
\hline 20 & + & + & + & + & + & + & + & - & + & + & + & + & + & + & + & + \\
\hline 21 & + & + & + & + & + & + & + & + & + & + & + & + & + & + & + & + \\
\hline 22 & + & + & + & - & + & + & - & - & - & + & + & - & + & + & + & - \\
\hline $\begin{array}{l}\text { Total } \\
\text { (STROBE) }\end{array}$ & $87 \%$ & $64 \%$ & $81 \%$ & $68 \%$ & $58 \%$ & $59 \%$ & $61 \%$ & $45 \%$ & $76 \%$ & $66 \%$ & $77 \%$ & $65 \%$ & $74 \%$ & $61 \%$ & $70 \%$ & $65 \%$ \\
\hline GRADE & B & B & B & B & B & B & B & B & B & B & B & B & B & B & B & B \\
\hline
\end{tabular}

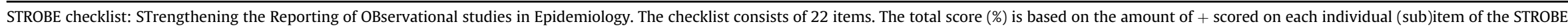
checklist.

GRADE: Grading of Recommendations Assessment, Development, and Evaluation. Scores range from A (highest level of evidence) to D (lowest level of evidence).

n/a: not applicable. 
Results on the association between the presence of low back pain and the presence of respiratory disorders.

\begin{tabular}{|c|c|c|c|c|c|c|c|c|}
\hline Study & Design & Sample size & Sex & Age & $\begin{array}{l}\text { Type of low back pain } \\
\text { (LBP) }\end{array}$ & $\begin{array}{l}\text { Type of respiratory disorder } \\
\text { (RD) }\end{array}$ & Main study result & Funding sources \\
\hline Åstrand (1987) & Cross-sectional & 391 & M & $35-65$ & Self-reported LBP & $\begin{array}{l}\text { Breathlessness in smokers, } \\
\text { asthmatics and on exertion }\end{array}$ & $\begin{array}{l}\text { - OR for breathlessness in case of LBP is } \\
2.5 \\
\text { - No association between LBP and } \\
\text { frequent cough or asthma }\end{array}$ & Not available \\
\hline $\begin{array}{l}\text { Bartholomeeusen et al. } \\
\text { (2011) }\end{array}$ & Cohort & 160,000 & $\mathrm{M}+\mathrm{F}$ & $\begin{array}{l}25-44 \\
45-64 \\
65-74\end{array}$ & $\begin{array}{l}\text { LBP with and without } \\
\text { radiculopathy }\end{array}$ & $\begin{array}{l}\text { - Acute upper respiratory } \\
\text { infection } \\
\text { - Flu } \\
\text { - Acute } \\
\text { bronchiolitis bronchitis/ } \\
\text { - Acute Laryngitis/tracheitis }\end{array}$ & $\begin{array}{l}\text { - Correlation between the incidence of } \\
\text { upper respiratory infections in } \\
\text { general and LBP in all female age } \\
\text { groups and a male subgroup aged } 45 \\
-64 \text {. } \\
\text { - Correlation between the incidence of } \\
\text { specific respiratory infections (i.e } \\
\text { laryngitis) and LBP in female aged } 25 \\
\text {-44. }\end{array}$ & Non-industry \\
\hline Clark et al. (2014) & Longitudinal & 266,000 & $M+F$ & $<75>$ & $\begin{array}{l}\text { Back pain (non- } \\
\text { specified) } \\
\text { - Most of the time in } \\
\text { past } 4 \text { weeks } \\
\text { - All the time in past } 4 \\
\text { weeks }\end{array}$ & Dyspnea & $\begin{array}{l}\text { - Prevalence of back pain with dyspnea } \\
\text { is } 64 \% \\
\text { - Prevalence of back pain without } \\
\text { dyspnea is } 18 \%\end{array}$ & Non-industry \\
\hline Heliovaara et al. (1991) & Cross-sectional & 5673 & $\mathrm{M}+\mathrm{F}$ & $30-64$ & $\begin{array}{l}\text { - Chronic LBP } \\
\text { - Sciatica } \\
\text { - Non-specified LBP }\end{array}$ & $\begin{array}{l}\text { - Non-specified RD } \\
\text { - Smoking }\end{array}$ & $\begin{array}{l}\text { Smokers have an increased risk of } \\
\text { having LBP }\end{array}$ & Not available \\
\hline Hestbaek et al. (2004) & Cross-sectional & 9567 & $\mathrm{M}+\mathrm{F}$ & $12-22$ & $\begin{array}{l}\text { - Ever } \\
-1-30 \text { days last year } \\
->30 \text { days last year }\end{array}$ & $\begin{array}{l}\text { - Atopic dermatitis/Hay fever } \\
\text { - Asthma }\end{array}$ & $\begin{array}{l}\text { - Positive associations between LBP } \\
\text { and asthma } \\
\text { - No association between LBP and } \\
\text { atopic dermatitis/hay fever }\end{array}$ & Non-industry \\
\hline Hestbaek et al. (2006) & Cross-sectional & 10,000 & $\mathrm{M}+\mathrm{F}$ & $20-30$ & Persistent LBP & $\begin{array}{l}\text { - Asthma } \\
\text { - Allergy }\end{array}$ & $\begin{array}{l}\text { - LBP and asthma in adolescence are } \\
\text { positively associated with future LBP } \\
\text { - No association between atopic } \\
\text { disease and future LBP } \\
\text { - Large degree of clustering of these } \\
\text { disorders, except for atopic disease }\end{array}$ & Non-industry \\
\hline $\begin{array}{l}\text { Hurwitz and } \\
\text { Morgenstern (1999) }\end{array}$ & Cross-sectional & 6836 & $M+F$ & $20-39$ & In last year & $\begin{array}{l}\text { - Asthma } \\
\text { - Hay fever } \\
\text { - Insect reaction } \\
\text { - Food allergy } \\
\text { - Animal allergy } \\
\text { - Other forms of allergy }\end{array}$ & $\begin{array}{l}\text { Subjects with a history of any allergy } \\
\text { are more likely to report LBP (OR 1.51) }\end{array}$ & Not available \\
\hline $\begin{array}{l}\text { Laban and Kucway } \\
\text { (2003) }\end{array}$ & Case-control & 69 & $\mathrm{M}+\mathrm{F}$ & $67-83$ & $\begin{array}{l}\text { Spinal canal stenosis } \\
\text { with night time sacro- } \\
\text { lumbalgia }\end{array}$ & $\begin{array}{l}\text { Endstage COPD with } \\
\text { pulmonary hypertension }\end{array}$ & $\begin{array}{l}\text { Pulmonary hypertension in those with } \\
\text { COPD and nocturnal lumbosacral } \\
\text { radiculopathy }\end{array}$ & Not available \\
\hline McIntosh et al. (2006) & Cohort & 7077 & $\mathrm{M}+\mathrm{F}$ & $18-65$ & $\begin{array}{l}\text { (Sub)acute LBP with or } \\
\text { without comorbidity }\end{array}$ & COPD (and/or other conditions) & $\begin{array}{l}\text { No differences LBP intensity and } \\
\text { duration between LBP group with } \\
\text { comorbidities and LBP group without } \\
\text { comorbidities }\end{array}$ & Not available \\
\hline Schäfer et al. (2014) & Cross-sectional & 98,619 & $M+F$ & $>64$ & Chronic LBP & Asthma/COPD + Allergy & $\begin{array}{l}\text { - Chronic LBP }+ \text { asthma/ } \\
\text { COPD + allergies triad } \\
\text { Observed/Expected ratio: } 2.4 \\
\text { - Prevalence of chronic LBP increases } \\
\text { more than expected by chance with } \\
\text { the number of comorbidities }\end{array}$ & $\begin{array}{l}\text { Non-industry }+ \text { industry } \\
\text { (health insurance company } \\
\text { BARMER/GEK) }\end{array}$ \\
\hline Schneider et al. (2007) & Cross-sectional & 7124 & $\mathrm{M}+\mathrm{F}$ & $18-79$ & In last 7 days & $\begin{array}{l}\text { - Allergic contact dermatitis } \\
\text { - Atopic eczema } \\
\text { - Food allergy }\end{array}$ & $\begin{array}{l}\text { All the investigated morbidities are } \\
\text { more common in subjects with LBP, } \\
\text { except for atopic eczema }\end{array}$ & Non-industry \\
\hline
\end{tabular}

- Atopic eczem$$
\text { except for atopic eczema }
$$

- OR for breathlessness in case of LBP is

frequent cough or asthm

(a) without

Most of the time in

past 4 weeks

weeks

- Hay fever

- Animal allergy

- Other forms of alle

pulmonary hypertension

Pulmonary hypertension in those with

(health insurance company 


\begin{tabular}{|c|c|c|c|c|c|c|c|c|}
\hline & & & & & & $\begin{array}{l}\text { Asthma pulmonale, Allergic } \\
\text { asthma })^{\mathrm{e}}\end{array}$ & & \\
\hline Smith et al. (2006) & Cross-sectional & 38,050 & $\mathrm{~F}$ & $\begin{array}{l}18-23 \\
45-50 \\
70-75\end{array}$ & In last year & $\begin{array}{l}\text { - Breathing difficulties/RD } \\
\text { - Asthma } \\
\text { - Allergy (incl. hay fever and } \\
\text { sinusitis) }\end{array}$ & $\begin{array}{l}\text { - Allergy associated with LBP among } 3 \\
\text { age cohorts } \\
\text { - RD associated with LBP among mid- } \\
\text { age and older women } \\
\text { - Asthma associated with LBP among } \\
\text { younger women }\end{array}$ & Non-industry \\
\hline Smith et al. (2009) & Cohort & 7499 & $\mathrm{~F}$ & $\begin{array}{l}18-23 \\
45-50 \\
70-75\end{array}$ & $\begin{array}{l}\text { - In last year } \\
\text { - Pre-existing and } \\
\text { newly developed }\end{array}$ & $\begin{array}{l}\text { - Pre-existing RD } \\
\text { - Newly developed RD }\end{array}$ & $\begin{array}{l}\text { - Women with pre-existing or newly } \\
\text { developed RD have an increased risk } \\
\text { for the development of LBP }\left(\mathrm{OR}^{g} 2.11\right) \\
\text { - Women with LBP or newly developed } \\
\text { LBP are more likely to develop RD }\end{array}$ & Non-industry \\
\hline & & & & & & & $\begin{array}{l}\text { - Allergy is associated with LBP } \\
\text { development } \\
\text { - Women with pre-existing }\end{array}$ & \\
\hline Smith et al. (2014) & Cohort & 58,458 & $\mathrm{~F}$ & $\begin{array}{l}18-23 \\
45-50 \\
70-75\end{array}$ & $\begin{array}{l}\text { - In last year } \\
\text { - Pre-existing and } \\
\text { newly developed }\end{array}$ & $\begin{array}{l}\text { - Pre-existing RD } \\
\text { - Newly developed RD }\end{array}$ & $\begin{array}{l}\text { - Women with pre-existing or newly } \\
\text { developed RD had an increased risk } \\
\text { for LBP development }\left(\mathrm{OR}^{g} 2.11\right) \\
\text { - Women with pre-existing and newly } \\
\text { developed LBP were more likely to } \\
\text { develop RD (OR: } 2.62)\end{array}$ & Non-industry \\
\hline $\begin{array}{l}\text { Synnot and Williams } \\
\text { (2002) }\end{array}$ & Cross-sectional & 60 & $\mathrm{M}+\mathrm{F}$ & $71 \pm 8$ & $\begin{array}{l}\text { - Ever } \\
\text { - In the past year } \\
\text { - In the past } 7 \text { days }\end{array}$ & $\begin{array}{l}\text { - Chronic bronchitis } \\
\text { - Emphysema-chronic airflow } \\
\text { limitation } \\
\text { COPD }^{\mathrm{f}}\end{array}$ & $\begin{array}{l}\text { Lifetime, } 12 \text {-month and } 7 \text { day } \\
\text { prevalence of LBP in patients with } \\
\text { chronic airflow limitation is } 69 \%, 58 \% \\
\text { and } 31 \% \text { (comparable to the general } \\
\text { population) }\end{array}$ & Not available \\
\hline Wright et al. (1995) & Cross-sectional & 34,000 & $\mathrm{M}+\mathrm{F}$ & $\begin{array}{l}18-39 \\
>65\end{array}$ & Non-specified LBP & Non-specified RD & $\begin{array}{l}\text { LBP is associated with smoking (OR } \\
1.52) \text { at all ages }\end{array}$ & Not available \\
\hline
\end{tabular}

- Hay fever (allergic rhinitis/ conjunctivitis)

- Allergic urticaria

- Chronic bronchitis

- Asthma (Bronchial asthma, Asthma pulmonale, Allergic

younger women

Women with LBP or newly developed

LBP are more likely to develop RD

developmen

with pre-existing and newly

RD (OR: 2.62)

e, 12-month and 7 day

$1.52)$ at all ages

Allergic contact dermatitis: 'a rash caused by detergents, cosmetic agents, nickel, etc'.

b Atopic eczema: 'itchy eczema, mainly at the level of the elbows and knees'.

c Allergic urticaria: 'transient, very itchy lesions'.

d Chronic bronchitis: 'nocturnal cough without cold, with productive cough in the morning for at least three months per year in two consecutive years'.

e Asthma: 'the diagnosis of asthma or having asthma-like symptoms, such as wheezing during cold weather or contact with animals or pollen, shortness of breath on exertion, more than one month cough, dry cough independently of colds'.

COPD: chronic obstructive pulmonary disease.

g OR: odds ratio. 
$\mathrm{RD}$, five articles with asthma and allergies, three with COPD, and one with respiratory infections.

\subsection{Dyspnea}

Only one study was found that reported the co-occurrence of dyspnea and LBP. Clark et al. (2014) noted that participants with dyspnea had a considerably higher prevalence of pain (pain interference, chest pain, back pain (BP) (not specified) and arthritis pain) than those without dyspnea (64\% vs. $18 \%$ ). After adjusting for other factors that might cause dyspnea (e.g., emphysema, asthma, COPD, obesity, smoking), or that might influence symptom reporting (i.e., depression and Activities of Daily Living (ADL) impairment), the relative risk (RR) for dyspnea was 1.76 (95\% confidence interval $(\mathrm{CI})$ 1.71-1.82) for having BP. After adjusting for socio-demographic and health-related variables, the RR for the simultaneous development of dyspnea with BP, compared with developing dyspnea without BP, was 3.26 (95\% CI 3.07-3.46).

\subsection{Non-specified respiratory disorders}

Five articles found a positive correlation between LBP and nonspecified RD (Heliovaara et al., 1991; Wright et al., 1995; Smith et al., 2006, 2009, 2014). Three articles searched for this correlation among women in three age categories: young, middle-aged and aged (Hurwitz and Morgenstern, 1999; Hestbaek et al., 2004, 2006). They observed a higher risk of developing LBP in women who had an existing or recently developed $\mathrm{RD}$ (Odds Ratios (OR) respectively 1.43 and 1.38 in young, 1.13 and 1.63 in middle-aged and 1.09 and 2.11 in aged women). On the other hand, they noted that women with existing or recently developed LBP had a greater probability of developing RD (Hurwitz and Morgenstern, 1999; Hestbaek et al., 2006). Schneider et al. (2007) reported an OR for having unspecified LBP with at least one diagnosis of RD of 1.3 (95\% CI 1.0-1.6) (Schneider et al., 2007).

Schäfer et al. (2014) found that chronic LBP had the highest number of associations with a range of medical conditions and was the most important mediator between them. A triad of "chronic LBP + asthma/COPD + allergies" with an observed/expected ratio of 2.4 and a prevalence of $1.4 \%$ was noted in the female subgroup. The prevalence of chronic LBP increased more than expected by chance with the number of comorbidities one person had (Prevalence Observed 79.13; Prevalence Expected 71.55, delta +7.58).

\subsection{Asthma}

Five articles investigated the link between asthma and LBP. In all articles, a positive relationship was found between asthma and LBP in young individuals aged $12-22$ years and 20-39 years (Hurwitz and Morgenstern, 1999; Hestbaek et al., 2004, 2006; Smith et al., 2006; Schneider et al., 2007). The probability of having a history of asthma is greater when LBP is reported in the past year $(p<0.05)$. Vice versa, the probability of reporting LBP in the past year is greater in a patient with a history of asthma $(p<0.05)$. The OR of reporting LBP in the past week was 30\% higher in patients with asthma compared to patients without a history of asthma ( $\mathrm{p}<0.05)$ (Schneider et al., 2007).

\subsection{Allergy}

The articles that investigated the link between asthma and LBP also described the correlation between LBP and allergy (Hurwitz and Morgenstern, 1999; Hestbaek et al., 2004, 2006; Smith et al., 2006; Schneider et al., 2007). In two articles, no significant correlation between allergy and LBP was found (Hestbaek et al., 2004,
2006). Schneider et al. (2007) examined the most common comorbidities in patients with LBP, more specifically hay fever and allergic contact dermatitis. Both were significantly more common in patients with LBP than in patients without LBP, with ORs of 1.21 (95\% CI 1.06-1.38) and 1.47 (95\% CI 1.29-1.67), respectively ( $\mathrm{p}<0.05$ ). In addition, allergic urticaria and food allergies were significantly more common in patients with LBP compared to subjects without LBP $(\mathrm{p}<0.05)$. Atopic eczema was not associated with a significantly higher risk of LBP ( $p>0.05)$.

Moreover, the risk of developing LBP is $50 \%$ higher if some form of allergy exists in the past or present (Hurwitz and Morgenstern, 1999). One study found a significant link between LBP and allergy in women of three age cohorts, i.e. $18-23$ years, $45-50$ years and 70-75 years (Smith et al., 2009).

\section{5. $C O P D$}

The relationship between LBP and COPD has been observed in three studies (Synnot and Williams, 2002; Laban and Kucway, 2003; McIntosh et al., 2006). The prevalence of reporting LBP ever and in the past year was respectively $69 \%$ and $58 \%$ in subjects with chronic airflow limitation. These patients had a diagnosis of chronic bronchitis, emphysema of asthma, chronic airflow limitation, COPD or chronic obstructive airways disease. The prevalence of reporting LBP ever and in the past year in the general population was respectively $11-84 \%$ and $3.9-65 \%$ (Balagué et al., 2012). Patients with acute LBP and comorbidities, such as COPD, did not have a significantly longer treatment duration, higher pain score measured by the Visual Analogue Scale (VAS) or worse functional outcome than patients with LBP without comorbidities (McIntosh et al., 2006).

\subsection{Respiratory infections}

Bartholomeeusen et al. (2011) found a significant positive correlation between the incidence of upper respiratory infections in general and the incidence of LBP in a female subgroup aged 25-44 years $(\mathrm{OR}=1.31,95 \% \mathrm{CI} 1.11-1.55, \mathrm{p}<0.05), 45-64$ years $(\mathrm{OR}=1.51,95 \% \mathrm{CI} 1.30-1.76, \mathrm{p}<0.05)$, and $65-74$ years $(\mathrm{OR}=1.33$, $95 \% \mathrm{CI} 1.00-1.76, \mathrm{p}<0.05)$, and a male subgroup aged $45-64$ years $(\mathrm{OR}=1.52,95 \% \mathrm{CI} 1.3-1.78, \mathrm{p}<0.05)$. Also, a correlation between the incidence of specific respiratory infections (i.e. laryngitis) and the incidence of LBP, compared with patients without LBP, was found in the female subgroup aged $25-44$ years $(\mathrm{OR}=2.31,95 \% \mathrm{CI}$ 1.61 to $3.31, \mathrm{p}<0.05$ ).

\section{Discussion}

A significant correlation between the presence of LBP and the presence of RD such as dyspnea, asthma, different forms of allergy, and respiratory infections was found. No correlation was found between the presence COPD and the presence of LBP. This is the first study providing an overview of the literature on this particular relation. Different underlying mechanisms might explain this correlation. Immunological, biomechanical, psychosocial and socioeconomic factors are purported to contribute to LBP (Balagué et al., 2012). Because these factors may contribute to, or be affected by a RD, the presence of RD may correlate with, and even predispose LBP.

Asthma, allergy, chronic bronchitis, COPD and other respiratory conditions involve inflammation and immune reactivity. Asthma and COPD are the two most common chronic inflammatory diseases of the lower airways (Caramori et al., 2015). Hay fever, food allergies and allergic dermatitis may reflect a more broadly reactive immune system. Consequently, it is conceivable that an infectious 
event (or some other physiological stressor) could induce a perturbation in the immune system towards a more proinflammatory state. It is known that pro-inflammatory cytokines play an important role in central and peripheral modulation of nociception. For example, tumor necrosis factor-a (TNF-a) not only plays a role in the pathophysiology of discogenic LBP and sciatica but also in chronic LBP (Wang et al., 2008). Therefore, it can be hypothesized that the relationship between RD and LBP can be explained by immunological factors.

Second, the results might be explained through the association between an altered breathing pattern and RD (Hodges and Gandevia, 2000; Synnot and Williams, 2002; Smith et al., 2014). For example, asthma is associated with functional breathing disorders. One third of women and one fifth of men treated for asthma in a single general practice had symptoms suggestive of dysfunctional breathing (Thomas et al., 2001). Dysfunctional breathing includes the hyperventilation syndrome (with symptoms of breathlessness, chest tightness, chest pain, and non-respiratory symptoms such as anxiety, light headedness and fatigue), unsteady and irregular breathing, frequent sighing and predominantly upper chest rather than diaphragmatic respiratory effort (Folgering, 1999). Roussel et al. (2009) found an altered breathing pattern in patients with chronic LBP during lumbopelvic control tests, and this was not related to pain severity. Thus, when challenging the trunk stabilizing muscles, patients with chronic LBP display an altered breathing pattern. A possible explanation is that some patients with chronic LBP favor the postural function of the diaphragm and thereby disadvantage the respiration, resulting in an altered breathing pattern with less contribution of the diaphragm (Roussel et al., 2009).

Furthermore, the diaphragm appears to function suboptimally in individuals with LBP. They show a higher diaphragm position and smaller diaphragm excursion during inspiration (Kolar et al., 2012), and more diaphragm fatigability compared to painfree individuals (Janssens et al., 2013a). Therefore, it can be suggested that, when the respiratory muscles are loaded, the diaphragm is less able to contribute to postural control (Hodges et al., 2001). Moreover, individuals with COPD who have IM weakness show a decreased postural stability compared to healthy controls (Janssens et al., 2013b). This impaired postural control may be an important factor in the onset and maintenance of LBP (Claeys et al., 2015). However, a significant correlation between the presence of COPD and LBP was not found. Likewise, exacerbations of asthma result in hyperinflation. Hyperinflation compromises the function of the IM by reducing their force-generating capacity and by impairing their mechanical advantage on the chest wall (Hill, 1991). A recent study regarding IM training in patients with LBP found that, after IM training, inspiratory muscle strength and postural control were significantly improved. During postural control while standing on an unstable support surface, an increased inspiratory muscle strength after IM training was significantly associated with improved postural control (Janssens et al., 2015). This favors the hypothesis that an impaired stabilizing function of the diaphragm can explain the relationship between RD and LBP. Moreover, this study found a clinically important decrease in LBP severity after IM training (Janssens et al., 2015). Although, this must be interpreted with caution because of the small sample size. Further research is necessary to establish that IM training is effective and if so, to investigate which individuals with LBP in particular may benefit from IM training (e.g., by mediation analyses).

Also, psychosocial components can be underlying the relationship between LBP and RD. Having a RD can result in enhanced anxiety, stress and hypervigilance towards bodily sensations (Panagioti et al., 2014). Also, the perception of unpleasantness (i.e., adverse dimension) of both dyspnea and pain are related (von
Leupoldt et al., 2009a). This suggestion is based on evidence supporting that the perception of dyspnea and pain share the same emotion-related (para)limbic brain areas such as the insula, anterior cingulate cortex and amygdala. For example, in asthmatic patients lower cortical responses of the insula have been found for both dyspnea and pain stimuli (von Leupoldt et al., 2009b).

An important mediator of the presence of RD is smoking. In this way, smoking history can be another important mechanism explaining the particular relationship with LBP. A meta-analysis showed that both smokers and ex-smokers have a higher incidence and prevalence of LBP in the past month and in the past year and a higher prevalence of chronic LBP compared to non-smokers. In addition, current smokers have had a higher prevalence of chronic LBP and LBP in the past year than ex-smokers (Shiri et al., 2010). Smoking does not only influence the onset and maintenance of LBP complaints, it also decelerates recovery of LBP when compared to non-smokers (Behrend et al., 2012). In addition, smoking has a negative effect on the outcome of spinal surgery, as smokers had a higher complication rate and longer hospitalization duration (Stienen et al., 2011). Vice versa, smoking cessation during LBP treatment improved the mean VAS pain rating with more than $15 \%$. The percentage of patients reporting a $>30 \%$ decrease in LBP was $31 \%$ in patients who had never smoked, $29 \%$ in ex-smokers and $17 \%$ in current smokers (Behrend et al., 2012). This improvement of $>30 \%$ can be considered as clinically significant (Ostelo et al., 2008).

A significantly higher prevalence of smoking was observed in a group of patients with chronic musculoskeletal pain compared to the general population (Orhurhu et al., 2015), although, no difference was observed between fibromyalgia, LBP and headache. The high prevalence of smoking among patients with chronic pain could be partly related to unique factors that exist in this patient population including opioid use and the clustering of addictive behaviors, such as daily smoking (Hooten et al., 2009a, 2009b; Højsted et al., 2013).

Smoking may induce LBP in different ways (Shiri et al., 2010). It is an important risk factor for osteoporosis. This may lead to LBP due to osteoporotic spinal fracture (Law and Hackshaw, 1997). Furthermore, smoking may reduce the perfusion of the intervertebral discs. This may lead to degenerative lesions in the intervertebral discs (Kauppila et al., 1997; Uematsu et al., 2001). Additionally, smoking may lead to amplification of pain by increasing the level of circulating pro-inflammatory cytokines (O'Loughlin et al., 2008). Moreover, smoking is associated with lower physical fitness, which in turn can lead to higher LBP scores (Heneweer et al., 2012; Mesquita et al., 2015). Finally, smoking enhances expiratory muscle strength, slightly increases IM strength and reduces IM endurance (Chen, 1988), and activates the sympathetic nervous system (Rodrigues et al., 2013). These autonomic changes may influence the breathing pattern, diaphragm function and may also explain the higher incidence of LBP in smokers.

Finally, there might be other contributing factors. It is known that socio-economic disadvantage is associated with general poor health. The association with LBP is less clear. However, patients from a lower socio-economic class are more likely to smoke and could therefore have a greater risk of LBP (Lallukka et al., 2014). Furthermore, gene expressions of an individual's psychological disposition associated with common co-morbidities, such as asthma, may be involved in the process of pain perception, pain signaling and the psychological process involved in pain, particularly in chronic LBP (Ferreira et al., 2013).

\subsection{Dyspnea}

Individuals who report shortness of breath are more likely to have various types of pain, including LBP. Dyspnea and pain share 
many features, e.g. similar experienced unpleasantness and intensity (von Leupoldt and Dahme, 2007). The most plausible explanation for the co-occurrence of dyspnea and pain is physical deconditioning (Schäfer et al., 2014). Higher levels of physical fitness, both muscular and aerobic, were strongly associated with having less LBP complaints (OR 0.54, 95\% CI 0.34-0.86 and OR 0.59, 95\% CI 0.35-0.99 respectively). On the other hand, too much physical activity might as well be hazardous for spinal health (OR $1.60,95 \%$ CI 1.05-2.44). Physical activity at a high enough intensity to improve physical fitness but not too high, may be important in the prevention of LBP (Heneweer et al., 2012). Recognizing and exploring the co-occurrence of dyspnea and pain could help health care providers to better understand patients' experiences, to select appropriate treatments, and possibly to treat both dyspnea and pain simultaneously.

\subsection{Allergy and asthma}

Three articles reported a significant correlation between allergy and LBP (Hurwitz and Morgenstern, 1999; Smith et al., 2006; Schneider et al., 2007), although two studies did not find such a relation (Hestbaek et al., 2004, 2006). In the latter studies, allergy and asthma were completely distinguished from one another, with allergy being defined as 'atopic dermatitis/hay fever with no evidence of asthma or asthma-like symptoms' (Hestbaek et al., 2004, 2006). In the three former articles, asthma was not distinguished from allergy. For asthma, more consistent results were found (Hurwitz and Morgenstern, 1999; Hestbaek et al., 2004, 2006; Smith et al., 2006). The chance of reporting LBP is greater for patients suffering from asthma or asthma-like symptoms when compared to patients without asthma. Vice versa, the occurrence of asthma is greater in patients who reported LBP ever or in the past year. Thus, when treating LBP in patients with asthma or asthmalike symptoms, an adequate management of asthma may also be important, together with an optimal LBP treatment. Also, it is known that allergy sufferers release greater amounts of proinflammatory cytokines, including Interleukin (IL)-1, IL-8 and TNF-a. These cytokines also play a significant role in chronic LBP (Hurwitz and Morgenstern, 1999; Wang et al., 2008). Furthermore, dysfunctional breathing may be an important focus in the rehabilitation in patients with asthma (Thomas et al., 2001), in particular in patients with exercise-induced asthma, where a stress condition (e.g. exercise) may lead to dysfunctional breathing (Barker and Everard, 2015).

\section{3. $C O P D$}

The prevalence of having an episode of LBP (69\%) or reporting LBP $(58 \%)$ in the past year in subjects with chronic airflow limitation is comparable to the prevalence of LBP in the general population (respectively $11-84 \%$ and 3.9-65\%) (Synnot and Williams, 2002). For acute LBP, a statistically significant although not clinically significant difference in VAS pain ( 0.5 points) and in total number of treatment days (2 days difference) was found in individuals with COPD compared to individuals without COPD (McIntosh et al., 2006). Thus, patients with COPD will likely recover from LBP at the same rate as individuals without COPD. A possible explanation for these results may be that patients with COPD have difficulty to differente pain caused by LBP from pain caused by COPD, and thus report less LBP (Synnot and Williams, 2002). On the other hand, patients with COPD do have an impaired balance control (Janssens et al., 2013b). The latter may play a key role in the onset and maintenance of LBP (Claeys et al., 2015). Therefore, future studies should investigate (low back) pain symptoms in patients with COPD in more detail, to distinguish different pain sources.

\subsection{Hyperventilation}

No articles on the link between hyperventilation and LBP were found. It is known that hyperventilation can be a reaction to pain. Thus, one may theoretically expect a higher prevalence of hyperventilation in patients with LBP (Glynn et al., 1981). Moreover, psychosocial factors, negative pain beliefs and job dissatisfaction are associated with the development of chronic LBP (Nicholas et al., 2011). Subjects with panic disorder show a condition of baseline hyperventilation (Grassi et al., 2014). pain, stress and emotional states, the diaphragm becomes mores flattened, hypertonic and relatively immobile (Courtney, 2009). As mentioned before, an altered functioning of the diaphragm can be an important factor in postural control impairments and the maintenance of LBP (Janssens et al., 2013b). However, these potential mechanisms must be investigated in future studies examining the correlation between LBP and hyperventilation.

\subsection{Clinical implications}

In patients with LBP, health care providers need to take into account the potential history of RD including asthma, different kinds of allergy, frequent respiratory infections and smoking status. Further research is necessary to determine whether the relationship between LBP and RD is causative. If so, future studies must reveal whether IM training or treatment of relevant RD would be beneficial for individuals with LBP who also report RD. Finally, an altered breathing pattern is associated with $\mathrm{RD}$, and this latter can be related to LBP. As a consequence, we can hypothesize that a correction of an altered breathing pattern could be a target of treatment.

\subsection{Limitations}

There are limitations to this study. First, the results were summarized qualitatively due to the heterogeneity of the study designs. Different study designs, outcome variables, measures and data analyses were found. Examples are the broad differences in sample sizen, age, and type of LBP. Bias in setting and participants (as presented in Table 1) needs consideration when indirectly comparing results across studies. Second, it must be kept in mind that apart from RD, other diseases are more frequently seen in individuals with LBP compared to individuals without LBP. Chronic LBP was found to be strongly associated with other chronic conditions that may cluster in a frail subgroup of the population (Hestbaek et al., 2003). Also, the prevalence of chronic LBP increases more than expected by chance with the number of comorbidities one person has (Schäfer, 2012). For this reason, chronic LBP might be the result of and not the cause of having other diseases. Third, none of the included designs could confirm a causative relationship between the presence of LBP and RD. Therefore, we recommend future studies to observe the onset, development and maintenance of LBP on the one hand and RD on the other hand in a prospective study design with a long-term follow-up. Risk factors can be calculated using logistic regression analysis. Mediation analyses can for example elucidate the underlying mechanisms of IM training.

\section{Conclusion}

A significant correlation between the presence of LBP and the presence of RD such as dyspnea, asthma, different forms of allergy, and respiratory infections was found. This review of the literature showed that individuals with a particular RD report higher rates of LBP and vice versa. However, mechanisms to explain this 
association are inconclusive at this point. No correlation was found between the presence COPD and the presence of LBP, and no articles were found on the correlation between hyperventilation and LBP. Based on this systematic review, further research is necessary to investigate which individuals with LBP in particular may benefit from IM training and whether history taking of RD will help practitioners to select these patients.

\section{Conflict of interest}

The authors declare no conflict of interest in the study.

\section{Ethical approval}

Not required.

\section{Funding}

This work was supported by The Research Foundation Flanders (FWO) (postdoctoral fellowship of Lotte Janssens with grant number $12 \mathrm{M} 9815 \mathrm{~N}$ ), the Agency for Innovation by Science and Technology - Flanders (IWT) (PhD fellowship Nina Goossens). The funders have no conflict of interest in the study design, in the collection, analysis and interpretation of data; in the writing of the manuscript; and in the decision to submit the manuscript for publication.

\section{Statement of Institutional Review Board approval of the study protocol}

The study conformed to the principles of the Declaration of Helsinki (1964) and was approved by the Ethics Committee of the University Hospitals Leuven.

\section{Acknowledgments}

We thank Prof. Dr. Koenraad Peers for his contribution to the study.

\section{References}

Åstrand NE. Medical, psychological, and social factors associated with back abnormalities and self reported back pain: a cross-sectional study of male employees in a Swedish pulp and paper industry. Br J Ind Med 1987:44:327-36.

Bartholomeeusen S, Van Zundert J, Truyers C, Buntinx F, Paulus D. Higher incidence of common diagnoses in patients with low back pain in primary care. Pain Pract 2011;12(1):1-6.

Behrend C, Prasarn M, Coyne E, Horodyski M, Wright J, Rechtine GR. Smoking cessation related to improved patient-reported pain scores following spinal care. J Bone Jt Surg Am 2012;94(23):2161-6.

Bachasson D, Wuyam B, Pepin J, Tamisier R, Levy P, Verges S. Quadriceps and respiratory muscle fatigue following high-intensity cycling in COPD patients. PLoS One 2013;8(12):e83432.

Balagué F, Mannion AF, Pellisé F, Cedraschi C. Non-specific low back pain. Lancet 2012;379:482-91.

Barker N, Everard ML. Getting to grips with dysfunctional breathing. Paediatr Respir Rev 2015;16(1):53-61. http://dx.doi.org/10.1016/j.prrv.2014.10.001.

Caramori G, Kirkham P, Barczyk A, Di Stefano A, Adcock I. Molecular pathogenesis of cigarette smoking-induced stable COPD. Ann N Y Acad Sci 2015;1340:55-64. http://dx.doi.org/10.1111/nyas.12619.

Chen HI. Effects of chronic smoking on respiratory muscle function. Chin J Physiol 1988;31(1):53-62.

Claeys K, Dankaerts W, Janssens L, Pijnenburg M, Goossens N, Brumagne S. Young individuals with a more ankle-steered proprioceptive control strategy may develop mild non-specific low back pain. J Electromyogr Kinesiol 2015;25(2): 329-38.

Clark N, Fan VS, Slatore CG, Locke E, Whitson HE, Nici L, et al. Dyspnea and pain frequently co-occur among Medicare managed care recipients. Ann Am Thorac Soc 2014;11(6):890-7.

Courtney R. The functions of breathing and its dysfunctions and their relationship to breathing therapy. Int J Osteopath Med 2009;12(3):78-85.
Decramer M, Demedts M, Rochette F, Billiet L. Maximal transrespiratory pressures in obstructive lung disease. Bull Eur Physiopathol Respir 1980;16:479-90.

Ferreira PH, Beckenkamp P, Maher CG, Hopper JL, Ferreira ML. Nature or nurture in low back pain? Results of a systematic review of studies based on twin samples. Eur J Pain 2013;17(7):957-71. http://dx.doi.org/10.1002/j.15322149.2012.00277.x.

Folgering $\mathrm{H}$. The pathophysiology of hyperventilation disorder. Monaldi Arch Chest Dis 1999;54:365-71

Grassi M, Caldirola D, DiChiaro NV, Dacco S, Pompili M, Perna G. Are respiratory abnormalities specific for panic disorder? A meta-analysis. Neuropsychobiology 2014;70(1):52-60

Glynn CJ, Lloyd JW, Folkhard S. Ventilatory response to intractable pain. Pain 1981:11(2):201-11.

Heliovaara M, Makela M, Knekt P, Impivara O, Aromaa A. Determinants of sciatica and low-back pain. Spine 1991;16:608-14.

Hestbaek L, Leboeuf-Yde C, Kyvik KO. Is comorbidity in adolescence a predictor for adult low back pain? A prospective study of a young population. BMC Musculoskelet Disord 2006; 7:29.

Hestbaek L, Leboeuf-Yde C, Kyvik KO, Vach W, Russell MB, Skadhauge L, et al. Comorbidity with low back pain: a cross-sectional population-based survey of 12to 22-year-olds. Spine 2004;29(13):1483-91.

Hestbaek L, Leboeuf-Yele C, Manniche C. Is low back pain part of a general health pattern or is it a separate and distinctive entity? A critical literature review of comorbidity with low back pain. J Manip Physiol Ther 2003;26:243-52.

Hill AR. Respiratory muscle function in asthma. J Assoc Acad Minor Phys 1991;2(3): $100-8$.

Hodges PW, Gandevia SC. Changes in intra-abdominal pressure during postural and respiratory activation of the human diaphragm. J Appl Physiol 2000;89(3): $967-76$.

Hodges PW, Heijnen I, Gandevia SC. Postural activity of the diaphragm is reduced in humans when respiratory demand increases. J Physiol 2001 Dec 15;537(Pt 3): 999-1008.

Heneweer H, Picavet HS, Staes F, Kiers H, Vanhees L. Physical fitness, rather than self-reported physical activities, is more strongly associated with low back pain: evidence from a working population. Eur Spine J 2012;21(7):1265-72.

Højsted J, Ekholm O, Kurita GP, Juel K, Sjøgren P. Addictive behaviors related to opioid use for chronic pain: a population-based study. Pain 2013;154(12): 2677-83.

Hooten WM, Townsend CO, Bruce BK, Shi Y, Warner DO. Sex differences in characteristics of smokers with chronic pain undergoing multidisciplinary pain rehabilitation. Pain Med 2009a;10:1416-25.

Hooten WM, Townsend CO, Bruce BK, Warner DO. The effects of smoking status on opioid tapering among patients with chronic pain. Anesth Analg 2009b;108: $308-15$.

Hurwitz EL, Morgenstern H. Cross-sectional associations of asthma, hay fever, and other allergies with major depression and low-back pain among adults aged 2039 years in the United States. Am J Epidemiol 1999;150:1107-16.

Janssens L, Brumagne S, McConnell AK, Hermans G, Troosters T, Gayan-Ramirez G. Greater diaphragm fatigability in patients with recurrent low back pain. Respir Physiol Neurobiol 2013a;188(2):119-23.

Janssens L, Brumagne S, McConnell AK, Claeys K, Pijnenburg M, Burtin C, et al Proprioceptive changes impair balance control in individuals with chronic obstructive pulmonary disease. PLoS One 2013b;8(3):e57949.

Janssens L, Brumagne S, Polspoel K, Troosters T, McConnell A. The effect of inspiratory muscles fatigue on postural control in people with and without recurrent low back pain. Spine 2010;35(10):1088-94.

Janssens L, McConnell AK, Pijnenburg M, Claeys K, Goossens N, Lysens R, et al. Inspiratory muscle training affects proprioceptive use and low back pain. Med Sci Sports Exerc 2015;47(1):12-9.

Kauppila LI, McAlindon T, Evans S, Wilson PW, Kiel D, Felson DT. Disc degeneration/ back pain and calcification of the abdominal aorta. A 25-year follow-upstudy in Framingham. Spine (Phila Pa 1976) 1997:22:1642-9.

Kolar P, Sulc J, Kyncl M, Sanda J, Cakrt O, Andel R, et al. Postural function of the diaphragm in persons with and without chronic low back pain. J Orthop Sports Phys Ther 2012;42(4):352-62.

Laban MM, Kucway EJ. Aeolus myth: chronic obstructive lung disease and nocturnal lumbosacral pain in association with lumbar spinal stenosis and pulmonary hypertension. Am J Phys Med Rehabil 2003;82(9):660-4.

Lallukka T, Viikari-Juntura E, Raitakari OT, Kähönen M, Lehtimäki T, Viikari J, et al. Childhood and adult socio-economic position and social mobility as determinants of low back pain outcomes. Eur J Pain 2014;18(1):128-38. http:// dx.doi.org/10.1002/j.1532-2149.2013.00351.x.

Law MR, Hackshaw AK. A meta-analysis of cigarette smoking, bone mineral density and risk of hip fracture: recognition of a major effect. BMJ 1997;315(7112): $841-6$.

McIntosh G, Hall H, Boyle C. Contribution of nonspinal comorbidity to low back pain outcomes. Clin J Pain 2006;22:765-9.

McKenzie DK, Butler JE, Gandevia SC. Respiratory muscle function and activation in chronic obstructive pulmonary disease. J Appl Physiol (1985) 2009;107: 621-9.

Mesquita R, Gonçalves CG, Hayashi D, Costa V de S, Teixeira D de C, de Freitas ER, et al. Smoking status and its relationship with exercise capacity, physical activity in daily life and quality of life in physically independent, elderly individuals. Physiotherapy 2015;101(1):55-61. 
Nicholas MK, Linton SJ, Watson PJ, Main CJ. Early identification and management of psychological risk factors ("yellow flags") in patients with low back pain: a reappraisal. Phys Ther 2011;91(5):737-53.

O'Loughlin J, Lambert M, Karp I, McGrath J, Gray-Donald K, Barnett TA, et al. Association between cigarette smoking and C-reactive protein in a representative, population based sample of adolescents. Nicotine Tob Res 2008;10:525-32.

Orhurhu VJ, Pittelkow TP, Hooten WM. Prevalence of smoking in adults with chronic pain. Tob Induc Dis 2015;13(1):17.

Ostelo RW, Deyo RA, Stratford P, Waddell G, Croft P, Von Korff M, et al. Interpreting change scores for pain and functional status in low back pain: towards international consensus regarding minimal important change. Spine 2008;33:90-4.

Panagioti M, Scott C, Blakemore A, Coventry PA. Overview of the prevalence, impact, and management of depression and anxiety in chronic obstructive pulmonary disease. Int J Chron Obstruct Pulmon Dis 2014;9:1289-306.

Polkey MI, Kyroussis D, Hamnegard CH, Mills GH, Green M, Moxham J. Diaphragm strength in chronic obstructive pulmonary disease. Am J Respir Crit Care Med 1996; 154:1310-7.

Rodrigues F, Araujo AA, Mostarda CT, Ferreira J, de Barros Silva MC, Nascimento AM, et al. Autonomic changes in young smokers: acute effect of inspiratory exercise. Clin Auton Res 2013;23(4):201-7. http://dx.doi.org/10.1007/s10286-013-0202-

Roussel N, Nijs J, Truijen S, Vervecken L, Mottram S, Stassijns G. Altered breathing patterns during lumbopelvic motor control tests in chronic low back pain: a case-control study. Eur Spine J 2009;18:1066-73.

Ruhe A, Fejer R, Walker B. Center of pressure excursion as a measure of balance performance in patients with non-specific low back pain compared to healthy controls: a systematic review of the literature. Eur Spine J 2011;20:358-68.

Schäfer I. Does multimorbidity influence the occurrence rates of chronic conditions? A claims data based comparison of expected and observed prevalence rates. PLoS One 2012:7:e45390.

Schäfer I, Kaduszkiewicz H, Wagner HO, Schön G, Scherer M, van den Bussche H. Reducing complexity: visualisation of multimorbidity by combining disease clusters and triads. BMC Public Health 2014;14:1285.

Smith M, Russell A, Hodges P. Disorders of breathing and continence have a stronger association with back pain than obesity and physical activity. Aust J Physiother 2006;52(1):11-6.

Smith MD, Russell A, Hodges PW. Do incontinence, breathing difficulties, and gastrointestinal symptoms increase the risk of future back pain? J Pain 2009;10(8):876-86
Smith MD, Russell A, Hodges PW. The relationship between incontinence, breathing disorders, gastrointestinal symptoms, and back pain in women: a longitudinal cohort study. Clin J Pain 2014;30(2):162-7.

Schneider S, Mohnen SM, Schiltenwolf M, Rau C. Comorbidity of low back pain representative outcomes of a national health study in the Federal Republic of Germany. Eur J Pain 2007;11:387-97.

Shiri R, Karppinen J, Leino-Arjas P, Solovieva S, Viikari-Juntura E. The association between smoking and low back pain: a meta-analysis. Am J Med 2010;123(1) 87.e7-35.

Stienen MN, Richter H, Prochnow N, Schnakenburg LF, Gautschi OP. Does smoking correlate with low back pain and the outcome of spinal surgery? Z Orthop Unfall 2011;149(3):317-23.

Synnot A. Williams M. Back pain in individuals with chronic airflow limitation and their partners - a preliminary prevalence study. Physiother Res Int 2002;7(4): 215-27.

Thomas M, McKinley RK, Freeman E, Foy C. Prevalence of dysfunctional breathing in patients treated for asthma in primary care: a cross sectional survey. BM] 2001;322:1098-100.

Uematsu Y, Matuzaki H, Iwahashi M. Effects of nicotine on the intervertebral disc: an experimental study in rabbits. J Orthop Sci 2001;6:177-82.

von Elm E, Altman DG, Egger M, Pocock SJ, Gøtzsche PC, Vandenbroucke JP, STROBE Initiative. The Strengthening the Reporting of Observational Studies in Epidemiology (STROBE) statement: guidelines for reporting observational studies. J Clin Epidemiol 2008;61(4):344-9.

von Leupoldt A, Dahme B. Experimental comparison of dyspnea and pain. Behav Res Methods 2007;39(1):137-43.

von Leupoldt A, Sommer T, Kegat S, Eippert F, Baumann HJ, Klose H, et al. Downregulation of insular cortex responses to dyspnea and pain in asthma. Am J Respir Crit Care Med 2009a;180(3):232-8. http://dx.doi.org/10.1164/ rccm.200902-03000C.

von Leupoldt A, Sommer T, Kegat S, Baumann HJ, Klose H, Dahme B, et al. Dyspnea and pain share emotion-related brain network. Neuroimage 2009b;48(1): 200-6. http://dx.doi.org/10.1016/j.neuroimage.2009.06.015.

Wang $\mathrm{H}$, Schiltenwolf $\mathrm{M}$, Buchner $\mathrm{M}$. The role of TNF-alpha in patients with chronic low back pain-a prospective comparative longitudinal study. Clin J Pain 2008;24(3):273-8. http://dx.doi.org/10.1097/AJP.0b013e31816111d3.

Wright D, Barrow S, Fisher AD, Horsley SD, Jayson MIV. Influence of physical and behavioral factors on consultations for back pain. Br J Rheumatol 1995;34: 156-61. 